\title{
PENERAPAN PMR PADA PEMBELAJARAN MATEMATIKA UNTUK MENINGKATKAN KEMANDIRIAN BELAJAR SISWA SMP
}

\author{
Nur Izzati \\ nurizzati@umrah.ac.id \\ Universitas Maritim Raja Ali Haji
}

\begin{abstract}
ABSTRAK
Kemandirian belajar siswa dalam matematika merupakan faktor yang turut menentukan keberhasilan belajar. Oleh sebab itu, kemandirian belajar ini perlu dikembangkan pada siswa. Pentingnya kemandirian belajar ini, sayangnya tidak seiring dengan penguasaan skill ini pada siswa. Karena itu, perlu adanya upaya untuk menerapkan suatu pendekatan pembelajaran yang diperkirakan dapat memicu peningkatan kemandirian belajar siswa dalam matematika. Penelitian ini menerapkan pendekatan Pendidikan Matematika Realistik (PMR) sebagai alternatif pendekatan pembelajaran yang diperkirakan dapat memicu peningkatan kompetensi tersebut. Tujuan penelitian ini adalah untuk mengetahui seberapa besar kontribusi penerapan PMR terhadap peningkatan Kemandirian Belajar Siswa dalam matematika (KBS), ditinjau dari keseluruhan dan level sekolah (tinggi, sedang, rendah). Penelitian ini menerapkan desain kuasi eksperimen. Sampel penelitian terdiri dari 239 orang siswa kelas VII pada tiga SMP Negeri di Kota Bandung, masing-masing mewakili sekolah level tinggi, sedang, dan rendah. Hipotesis penelitian diuji pada taraf signifikansi 5\%, menggunakan Uji-t Berpasangan, Uji Peringkat Bertanda Wilcoxon, Uji-t Independen, Uji Mann-Whitney, Hasil penelitian ini menunjukkan bahwa: (1) terdapat peningkatan yang signifikan pada KBS bagi siswa yang belajar matematika melalui pendekatan PMR, ditinjau dari keseluruhan, dan pada sekolah level rendah, sedangkan bagi siswa yang belajar matematika melalui pendekatan PB, tidak mengalami peningkatan KBS secara signifikan, baik ditinjau dari keseluruhan maupun berdasarkan level sekolah; (2) terdapat perbedaan peningkatan KBS antara siswa yang belajar matematika melalui pendekatan PMR dan PB, namun perbedaan tersebut kecil sehingga tidak signifikan. Ditinjau dari peningkatan pada aspek-aspek KBS, terdapat perbedaan yang signifikan pada aspek strategi kognitif antara siswa yang belajar matematika melalui pendekatan PMR dan PB.
\end{abstract}

Kata Kunci: kemandirian belajar siswa dalam matematika, pendidikan matematika realistik (PMR)

\section{PENDAHULUAN}

\section{Latar Belakang Masalah}

Kemandirian belajar siswa dalam matematika merupakan faktor yang turut menentukan keberhasilan belajar. Banyak data hasil penelitian menunjukkan bahwa kemandirian belajar mempunyai pengaruh positif terhadap pembelajaran dan pencapaian hasil belajar. Seperti temuan dari studi Darr dan Fisher (2004), Reyero dan Tourón (dalam Montalvo dan Torres, 2004), Pintrich dan Groot (1990), dan Zimerman dan Martinez-Pons (1986), yang menunjukkan bahwa kemandirian belajar berkorelasi kuat dengan kesuksesan seorang siswa. Sebaliknya, hasil studi yang 
dilakukan oleh Schloemer dan Brenan, juga oleh Borkowski dan Thorpe (dalam Abdullah, 2007) menunjukkan bahwa kegagalan terhadap kemandirian dalam proses belajar menjadi penyebab utama dari rendahnya prestasi belajar.

Hal serupa dikemukakan oleh Long (dalam Sumarmo, 2006). Ia memandang belajar sebagai proses kognitif yang dipengaruhi oleh beberapa faktor seperti keadaan individu, pengatahuan sebelumnya, sikap, pandangan individu, konten, dan cara penyajian. Satu di antara sub-faktor penting dari keadaan individu yang mempengaruhi belajar adalah kemandirian belajar.

Kemandirian belajar berkaitan dengan bagaimana siswa menjadi tuan dari proses belajar mereka sendiri. Menurut Darr dan Fisher (2004), seorang siswa mandiri adalah seseorang yang secara aktif terlibat dalam memaksimalkan kesempatan dan kemampuannya untuk belajar. Mereka tidak hanya mengontrol aktivitas kognitif (metakognisi), tetapi juga mengembangkan keterampilan yang berkenaan dengan kemauan yang memungkinkan pengaturan terhadap sikap, lingkungan dan perilaku untuk meningkatkan hasil belajar yang positif.

Kemandirian belajar merupakan keterampilan belajar seumur hidup.
Vienman, et al. (Abdullah, 2007), memandang bahwa keterampilan kemandirian belajar merupakan hal penting, tidak hanya untuk memandu seseorang dalam belajar pada sekolah formal tetapi juga untuk meng-update pengetahuannya setelah lulus sekolah.

Pentingnya kemandirian siswa dalam belajar tidak seiring dengan peningkatan keterampilan ini pada siswa. Sering guru mengeluhkan, bahwa banyak siswa mereka yang bersifat seperti "paku", ia baru bergerak ketika dipukul dengan palu. Artinya, siswa baru bekerja apabila sudah diinstruksikan oleh guru mereka. Banyak siswa yang belum termotivasi untuk belajar sendiri dan tanggung jawab mereka terhadap tugas-tugas belajar masih rendah. Hal ini dapat dilihat dari banyaknya siswa yang tidak mengerjakan pekerjaan rumah (PR) yang ditugaskan oleh guru mereka.

Begitu juga halnya ketika mengerjakan tugas-tugas matematika, siswa menunjukkan rasa kurang percaya diri terhadap kebenaran jawabannya. Untuk meyakinkan mereka apakah jawabannya sudah benar atau belum, siswa harus bertanya dulu kepada gurunya. Ada pula yang menunggu jawaban temannya untuk kemudian disalin, atau menunggu pembahasan oleh guru mereka. Hal ini 
menunjukkan bahwa siswa belum mandiri dalam belajar matematika.

Fakta empiris tentang rendahnya kemandirian belajar siswa yang dikemukakan di atas, sejalan dengan beberapa hasil penelitian yang dirangkum oleh De Corte, Verschaffel, dan Op'T Eynde (2000). Hasil-hasil penelitian ini menunjukkan adanya kelemahan yang mendasar pada komponen-komponen keterampilan kemandirian bagi banyak siswa.

Kajian yang telah dikemukakan di atas, menunjukkan bahwa kemandirian belajar merupakan kompetensi penting yang harus dikembangkan pada siswa. Pembelajaran selama ini belum memberikan perhatian terhadap pengembangan kompentensi ini. Oleh sebab itu, kita perlu mengupayakan suatu pendekatan pembelajaran yang dapat memberikan pengalaman belajar bagi siswa, dan memberikan ruang bagi siswa untuk menumbuhkembangkan kemandirian belajar mereka dalam matematika.

Proses pembelajaran matematika di kelas hendaknya mampu memupuk keberanian, kepercayaan diri dan motivasi siswa untuk menyampaikan pemikirannya kepada teman-temannya, gurunya, maupun orang lain. Keberanian, kepercayaan diri dan motivasi siswa memungkinkan untuk tumbuh subur jika pengajaran di kelas menanamkan sikap menghargai kontirbusi siswa. Dengan demikian, siswa akan bangga dan lebih percaya diri.

Menurut Montalvo dan Torres (2004), intervensi dalam model pengajaran harus difokuskan pada pengadaan lingkungan belajar yang alami, penggunaan tugas-tugas kontekstual yang menarik dan diperlukan siswa, karena hal ini akan memungkinkan mereka untuk berkontribusi dalam membuat generalisasi tentang apa yang telah mereka pelajari.

Pendekatan pendidikan matematika realistik (PMR) merupakan pendekatan pembelajaran yang menghargai kontribusi siswa, dan itu menjadi salah satu karakteristiknya. PMR merupakan konsep belajar yang membantu guru mengaitkan antara materi yang diajarkan dengan situasi dunia nyata siswa (kontekstual) dan mendorong siswa membuat hubungan antara pengetahuan yang dimilikinya dengan penerapannya dalam kehidupan mereka sebagai anggota keluarga dan masyarakat. Pembelajaran diawali dengan menyajikan masalah kontekstual yang dikenal siswa, hal ini akan menimbulkan ketertarikan siswa untuk memahami permasalahan tersebut lebih jauh sehingga menghasilkan pemecahan yang menjadi kontribusi siswa. 
Selain kemandirian belajar, dalam mengimplementasikan pembelajaran dengan pendekatan PMR ini, juga perlu memperhatikan level sekolah. Setiap level sekolah mempunyai karakteristik yang berbeda-beda. Misalnya, sekolah level tinggi biasanya mempunyai tingkat kedisiplinan dan kemampuan awal yang lebih tinggi dibandingkan dengan sekolah level sedang dan rendah, begitu pula dalam hal sarana dan prasarana. Hal ini tentunya akan mempengaruhi tingkat kemandirian siswa dalam belajar dan pada akhirnya akan mempengaruhi prestasi belajar siswa.

Karena itu, faktor level sekolah perlu diperhatikan pada penelitian ini, untuk melihat tingkat keberhasilan penerapan pendekatan PMR pada pembelajaran matematika di setiap level sekolah kemandirian belajar siswa dalam matematika.

\section{Pendidikan Matematika Realistik (PMR)}

Gravemeijer

mengemukakan tiga prinsip utama dari PMR berkaitan dengan disain instruksional, yaitu penemuan kembali secara terbimbing (guided reinvention), fenomena didaktik (didactical phenomenology), dan pemodelan (emerging models). Dari tiga prinsip utama PMR ini, lahirlah lima karakteristik PMR, yaitu: menggunakan konteks; menggunakan model, situasi, skema dan simbol-simbol; menggunakan kontribusi siswa (sumbangan pemikiran dari siswa); mengaitkan sesama topik dalam matematika (intertwine); dan menggunakan metode interaktif dalam belajar matematika.

Pembelajaran dengan metode interaktif melatih keberanian siswa dalam mengemukakan pendapat. Untuk memfasilitasi terjadinya interaktif (terjadinya komunikasi multi arah), pada penelitian ini, pembelajaran dengan pendekatan PMR dilaksanakan dengan setingan kelompok-kelompok kecil. Pembelajaran, dimulai dengan kerja kelompok, kemudian dilanjutkan dengan forum diskusi kelas. Biasanya, siswa lebih percaya diri jika bekerja bersama (berkelompok) dibadingkan dengan bekerja secara individu.

Hal senada juga dikemukakan oleh Puncochar dan Fox (dalam Mohan dan Lundeberg, 2009), di mana mereka mengatakan bahwa dua kepala biasanya lebih percaya diri dari satu kepala, bahkan ketika jawaban salah pun mereka masih percaya diri. Dengan demikian, penerapan pendekatan PMR dengan setingan belajar kelompok-kelompok kecil diharapkan dapat menumbuhkan rasa percaya diri 
siswa terhadap kemampuan mereka, dan ini adalah merupakan modal awal tumbuhnya kemandirian belajar siswa dalam matemtika.

\section{Kemandirian Belajar}

Dari berbagai definisi tentang kemandirian belajar, Pintrich dan Groot (1990) menyimpulkan hanya tiga komponen penting untuk kecakapan di kelas. Pertama, kemandirian belajar meliputi strategi metakognitif siswa untuk merencanakan, memonitor dan memodifikasi kognisi mereka. Kedua, pengaturan dan pengontrolan siswa terhadap usaha mereka pada tugas-tugas akademik di kelas. Misalnya, siswa yang cakap bertahan pada tugas-tugas sulit, mereka tidak cepat menyerah, dan mereka tetap konsentrasi dalam tugas, walaupun ada gangguan di kelas, sehingga memungkinkan mereka untuk melakukan yang lebih baik. Ketiga, aspek penting kemandirian belajar meliputi konsep keberadaan strategi kognitif yang digunakan siswa untuk belajar, mengingat dan memahami materi. Lebih jauh Pintrich dan Groot (1990) mengemukakan bahwa pengetahuan strategi kognitif dan metakognitif saja tidaklah cukup untuk meningkatkan kemampuan siswa. Siswa juga harus dimotivasi untuk menggunakan strategi-strategi itu, dan juga mengatur kongisi dan usaha mereka.

Menurut Bandura (dalam Cobb, 2003), motivasi mempengaruhi bagaimana dan mengapa orang belajar dengan baik, motivasi juga mempengaruhi kemampuan mereka. Eccles (dalam Pintrich dan Groot, 1990) mengemukakan tiga komponen motivasi yang berhubungan dengan tiga komponen lainnya dari kemandirian belajar, yaitu; komponen harapan, komponen nilai, dan komponen sikap. Komponen harapan meliputi keyakinan siswa terhadap kemampuannya untuk melakukan tugas, seperti kemampuan menyadari tentang sesuatu (perceived competence), self-efficacy, dan keyakinan melakukan pengontrolan. Esensi dari komponen harapan berkenaan dengan jawaban dari pertanyaan, "Dapatkah saya melakukan tugas ini?"

Komponen nilai meliputi tujuan siswa untuk melakukan tugas dan keyakinan siswa akan pentingnya tugas serta ketertarikan mereka terhadap tugas. Meskipun komponen ini diartikan dalam berbagai cara, (seperti: tujuan belajar atau tujuan melakukan, orientasi instrinsik atau ekstrinsik, menilai tugas dan ketertarikan instrinsik), esensi komponen motivasi ini adalah alasan siswa untuk melakukan tugas. Dengan kata lain, merupakan 
jawaban dari pertanyaan, "Mengapa saya melakukan tugas ini?"

Komponen sikap berkenaan dengan sikap siswa atau reaksi emosi siswa terhadap tugas. Hal penting bagi siswa berkenaan dengan komponen ini melipulti pertanyaan, "Bagaimana perasaan saya tentang tugas ini?" Ada berbagai reaksi sikap yang mungkin relevan, misalnya; rasa marah, bangga, rasa bersalah, tapi dalam konteks belajar di sekolah, kelihatannya ada satu yang paling penting yaitu tes anxiety. Tes anxiety berkaitan dengan persepsi terhadap kemampuan.

Menurut Bandura (1997), selfefficacy berkaitan dengan keyakinan seseorang terhadap kemampuannya untuk belajar atau melakukan keahlian/keterampilan pada tingkat yang ditentukan. Lebih jauh Bandura (1997) menyatakan bahwa self-efficacy mempunyai hubungan sebab akibat dengan pengaturan motivasi dan tindakkan.

Berdasarkan beberapa pendapat tentang kemandirian belajar yang dikemukakan di atas, pada penelitian ini dirumuskan beberapa indikator kemandirian yang dikembangkan dan diukur, yaitu: keyakinan motivasi, manajemen sumber daya, strategi metakognitif, dan strategi kognitif. Keyakinan motivasi meliputi keyakinan akan pentingnya matematika dan ketertarikan terhadap matematika, orientasi tujuan intrinsik dan ekstrinsik, dan self-efficacy. Manajemen sumber daya meliputi aspek manajemen waktu belajar, mendiagnosis kebutuhan belajar dan mencari serta memanfaatkan sumber belajar yang relevan. Strategi metakognitif terdiri dari aspek kemampuan mengontrol/mengatur kognisi dan memonitor serta mengevaluasi diri, sedangkan strategi kognitif meliputi aspek latihan/membaca kembali, mengelaborasi, dan mengorganisasikan materi.

\section{Mengukur Kemandirian Berlajar}

Ada beberapa prosedur yang dapat digunakan untuk mengukur kemandirian belajar. Winne dan Perry (2005) membedakan instrumen untuk mengukur kemandirian belajar dalam dua jenis, yaitu: (1) instrumen yang mengukur kemandirian belajar sebagai suatu sikap; (2) instrumen yang mengukur kemandirian belajar sebagai suatu aktivitas/kejadian. Instrumen yang termasuk dalam kategori pertama, yaitu angket pelaporan-diri (self-reporting questionnaires), interviu terstruktur, dan penilaian oleh guru, sedangkan yang termasuk kategori kedua adalah thinkaload protocols, metode mendeteksi kesalahan pada tugas, dan pengukuran melalui pengamatan. 
Menurut Montalvo dan Tores (2004), hingga saat ini, instrumen yang paling sering digunakan untuk mengukur kemandirian belajar adalah angket pelaporan-diri (self-reporting questionnaires). Beberapa angket pelaporan-diri yang banyak digunakan adalah: The Learning and Study Strategies Inventory (LASSI), The Motivated Strategies for Learning Questionnares (MSLQ), dan The Components of SelfRegulated Learning (CSRL).

LASSI terdiri dari 77 item dengan lima kategori pilihan, yang dirancang untuk menilai strategi belajar yang digunakan oleh mahasiswa. Angket ini memuat 10 indikator kemandirian belajar, yaitu: sikap, motivasi, pengaturan waktu, anxiety, konsentrasi, proses informasi, pemilihan ide-ide pokok, menggunakan teknik dan materi-materi yang mendukung, penilaian diri, dan strategi ujian (Winne dan Perry, 2005).

MSLQ terdiri dari 81 item dengan tujuh kategori pilihan, yang dirancang untuk mengukur komponen-komponen motivasi dan penggunaan strategi belajar. Komponen-komponen motivasi yaitu; mengontrol keyakinan belajar, selfefficacy, orientasi tujuan intrinsik and ekstrinsik, menilai tugas, dan tes anxiety. Strategi-strategi belajar meliputi; strategi kognitif dan metakognitif (latihan, elaborasi, pengorganisasian, berpikir kritis, pengaturan metakognitif), strategi manajemen sumber daya (mengatur waktu belajar, mengatur usaha, mencari bantuan, belajar dengan teman sebaya) (Winne dan Perry (2005). Sub indikator dari pengaturan metakognitif meliputi: perencanaan, pengamatan (monitoring), dan pengaturan (Cobb, 2003).

CSRL juga dirancang untuk mengukur komponen-komponen motivasi dan kognitif yang terlibat dalam kemandirian belajar. Komponenkomponen tersebut adalah: menentukan tujuan, mengontrol keyakinan (belief), selfesteem, elaborasi, dan mengamati pemahaman sendiri (Montalvo dan Tores, 2004).

Pada penelitian ini, kemandirian belajar siswa dalam matematika diukur menggunakan angket pelaporan-diri (selfreporting questionnaires), yang merupakan jenis instrumen yang banyak digunakan. Angket ini terdiri dari pernyataanpernyataan yang dikembangkan dari indikator-indikator kemandirian belajar dalam matematika yang diukur pada penelitian ini, seperti yang sudah dijelaskan sebelumnya. Montalvo dan Tores (2004) mengatakan bahwa MSLQ telah diujikan dan divalidasi dalam level 
pendidikan yang berbeda, yaitu universitas dan non-universitas. Lebih jauh, Wolters, Pintrich, dan Karabenick (2003), mengatakan bahwa MSLQ merupakan skala yang cocok digunakan untuk populasi dengan usia lebih muda dan dewasa. Karena itu, dalam menyusun angket yang digunakan pada penelitian ini, peneliti terinspirasi oleh MSLQ .

Angket tersebut berisi pernyataan positif dan negatif dengan lima kategori pilihan (lima skala likert), yaitu SS (Sangat Setuju), S (Setuju), TY (bila tidak yakin/ragu-ragu atau tidak tahu), TS (Tidak Setuju), dan STS (Sangat Tidak Setuju).

\section{Mengembangkan Kemandirian \\ Belajar dalam Matematika}

Kemandirian belajar bukanlah keterampilan yang secara otomatis berkembang seiring dengan bertambahnya usia siswa, namun kemandirian belajar ini perlu diajarkan dan dipelihara. Siswa diharapkan untuk mengembangkan keterampilan kemandirian ini, agar mereka dapat berinteraksi dengan ide-ide matematis dengan cara yang aktif dan konstruktif.

Zimmerman, Bonner, dan Kovach (1996), mengemukakan bahwa latihan kemandirian belajar dapat meningkatkan semangat siswa dan guru dengan meningkatkan partisipasi siswa dalam kelas, kualitas diskusi, dan ketertarikan siswa terhadap topik pelajaran. Lebih jauh, Zimmerman, Bonner, dan Kovach (1996) mengemukakan bahwa peningkatan semangat siswa merupakan hasil yang alami dari peningkatan pemahaman dan keterlibatan mereka serta kesadaran terhadap self-efficacy mereka, sedangkan peningkatan semangat guru merupakan imbas dari melihat pertumbuhan siswanya dalam self-confidence ketika mereka menemukan cara belajar yang benar-benar bekerja. Dengan demikian, sebagai konsekuensinya adalah membuat proses pembelajaran yang lebih nyaman dan menarik bagi setiap siswa, serta menumbuhkan disposisi positif terhadap pembelajaran.

De Corte, Verschaffel, dan Op' T Eynde (2000) mempelajari beberapa penelitian yang mencoba mengembangkan lingkungan kelas yang dapat mendukung pengembangan kemandirian belajar di bidang matematika. Kemudian, mereka menyimpulkan bahwa komponenkomponen pengajaran yang membantu perkembangan kemandirian belajar adalah: a) Memberikan tugas-tugas realistik dan menantang; b) Adanya variasi dalam metode pengajaran meliputi: latihan terbimbing, bekerja dalam kelompok kecil 
dan pengajaran klasikal, dan; c) Menciptakan ruang kelas yang membantu perkembangan disposisi positif terhadap pembelajaran matematika.

Selanjutnya, menurut Montalvo dan Torres (2004), model-model pengajaran dalam mengajar kemandirian menekankan pada pentingnya praktek refleksi diri, scaffolding dan pembelajaran kolaboratif. Lebih jauh, mereka menekankan bahwa intervensi dalam model pengajaran harus difokuskan pada pengadaan lingkungan belajar yang alami, tidak ada paksaan, dan menggunakan tugas-tugas kontekstual yang menarik dan diperlukan siswa, karena ini akan memungkinkan mereka untuk membuat generalisasi tentang apa yang telah mereka pelajari terhadap situasisituasi dari diri mereka, akademik dan kehidupan sosial mereka. Zimmerman (dalam Darr dan Fisher, 2004) menegaskan bahwa siswa dengan scaffolding yang tepat, mengalami kemajuan melalui tahaptahap observasi, perlombaan dan pengontrolan diri sebelum akhirnya tiba pada apa yang disebut dengan kemandirian.

Kemudian, menurut Camahalan (2006), aktivitas-aktivitas pengajaran harus memberikan kesempatan untuk mendiskusikan pelajaran. Diskusi ini menimbulkan interaksi sosial antar siswa, karena adanya saling memberi dan menerima pengetahuan dan keterampilan. Suatu ungkapan penting yang dikemukakan Camahalan (2006) tentang kemandirian belajar adalah bahwa orang belajar dengan melakukan.

PMR merupakan salah satu pendekatan pembelajaran yang mengakomodasi karakteristik pengajaran yang mendukung perkembangan kemandirian belajar, seperti yang dikemukakan di atas. Menggunakan tugastugas kontekstual, berdiskusi dan berkolaborasi dalam proses pembelajaran (interaktif) merupakan karakteristik pendekatan PMR, sedangkan latihan terbimbing dalam menemukan kembali konsep-konsep matematis (reinvention) merupakan salah satu prinsip utama PMR. Dengan pemberian scaffolding yang tepat dan diiringi dengan refleksi diri, maka proses reinvention ini dapat berjalan lebih baik. Karena itu, penerapan PMR pada pembelajaran matematika dengan setingan kelompok-kelompok kecil sangat memungkinkan dapat meningkatkan kemandirian belajar siswa dalam matematika.

\section{Tujuan Penelitian}

Tujuan penelitian ini adalah untuk menganalisis peningkatan dan perbedaan peningkatan kemandirian belajar siswa 
dalam matematika antara siswa yang belajar dengan pendekatan PMR dan yang belajar dengan pendekatan Pembelajaran Biasa (PB) ditinjau dari keseluruhan sampel dan berdasarkan level sekolah (tinggi, sedang, rendah).

\section{Hipotesis Penelitian}

Hipotesis penelitian ini adalah:

a. Terdapat peningkatan kemandirian belajar siswa dalam matematika setelah mendapat pembelajaran.

b. Siswa yang belajar dengan pendekatan PMR memperoleh peningkatan kemandirian belajar yang lebih tinggi daripada siswa yang belajar dengan pendekatan PB.

c. Terdapat peningkatan kemandirian belajar siswa dalam matematika pada sekolah level tinggi setelah mendapat pembelajaran.

d. Siswa pada sekolah level tinggi yang belajar dengan pendekatan PMR memperoleh peningkatan kemandirian belajar dalam matematika yang lebih tinggi daripada siswa yang belajar dengan pendekatan PB.

e. Terdapat peningkatan kemandirian belajar siswa dalam matematika pada sekolah level sedang setelah mendapat pembelajaran.

f. Siswa pada sekolah level sedang yang belajar dengan pendekatan PMR memperoleh peningkatan kemandirian belajar dalam matematika yang lebih tinggi daripada siswa yang beajar dengan pendekatan PB.

g. Terdapat peningkatan kemandirian belajar siswa dalam matematika pada sekolah level rendah setelah mendapat pembelajaran.

h. Siswa pada sekolah level rendah yang belajar dengan pendekatan PMR memperoleh peningkatan kemandirian belajar dalam matematika yang lebih tinggi daripada siswa yang belajar dengan pendekatan PB.

\section{METODE PENELITIAN}

Penelitian ini menerapkan desain kuasi eksperimen (quasi-experimental design), karena subjek untuk kelas eksperimen dan kelas kontrol pada penelitian ini, tidak dipilih secara acak tetapi peneliti menerima keadaan subjek seadanya. Hal ini disebabkan oleh sistem sekolah yang tidak memungkinkan peneliti melakukan pemilihan subjek secara acak. Selain itu, penelitian ini berlangsung dalam lingkungan kehidupan nyata, karena itu pelaksanaan penelitian pada kedua kelompok sampel tidak mungkin identik. Alasan yang peneliti kemukakan di atas merujuk kepada pendapat Ary, Jacobs, dan Sorensen (2010), serta Muijs (2004) 
tentang pengertian desain kuasi eksperimen.

Kuasi eksperimen yang diterapkan pada penelitian ini menggunakan desain pretes-postes, kelompok kontrol tidak acak (Nonrandomized Control Group, PretestPosttest Design). Secara singkat, desain tersebut digambarkan sebagai berikut (Ary, Jacobs, dan Sorensen, 2010):

$\begin{array}{llll}\text { E } & \mathrm{Y}_{1} & \mathrm{X} & \mathrm{Y}_{2} \\ \mathrm{C} & \mathrm{Y}_{1} & & \mathrm{Y}_{2}\end{array}$

Keterangan:

$\mathrm{E}=$ kelompok eksperimen

$\mathrm{C}=$ kelompok kontrol

$\mathrm{Y}_{1}=$ pengisian skala kemandirian belajar siswa dalam matematika (KBS) (pengambilan data awal KBS).

$\mathrm{X}$ = perlakuan (pembelajaran dengan pendekatan PMR)

$\mathrm{Y}_{2}=$ pengisian skala kemandirian belajar siswa dalam matematika (pengambilan data akhir KBS).

Penelitian ini melibatkan tiga variabel yaitu, variabel bebas, variabel terikat, dan variabel kontrol. Variabel bebas terdiri dari pendekatan pembelajaran PMR dan $\mathrm{PB}$, veriabel terikat terdiri dari kemandirian bealajar siswa dalam matematika, dan yang termasuk variabel kontrol adalah level sekolah.

Sekolah yang terpilih sebagai sampel penelitian ini adalah SMP Negeri
12 Bandung mewakili sekolah-sekolah level tinggi, SMP Negeri 15 Bandung mewakili sekolah-sekolah level sedang, dan SMP Negeri 29 Bandung mewakili sekolah-sekolah level rendah. Penelitian dilakukan bulan Maret s.d. Juni 2011.

Pada penelitian ini, instrumen yang digunakan terdiri dari skala kemandirian belajar siswa dalam matematika, lembar observasi untuk mengamati proses pembelajaran, dan perangkat pembelajaran yang meliputi Rencana Pelaksanaan Pembelajaran (RPP) serta Lembar Kerja Siswa (LKS).

\section{HASIL DAN PEMBAHASAN}

\section{Hasil Penelitian}

Data KBS berupa data kualitatif yang dikuantitatifkan dengan cara pemberian skor terhadap setiap kategori untuk setiap item. Pemberian skor ini ditentukan dengan Metode Rating yang Dijumlahkan, yaitu merupakan metode penskalaan pernyataan sikap yang menggunakan distribusi respon sebagai dasar penentuan nilai skalanya. Kategorikategori respon dalam bentuk kategori ordinal akan di letakkan pada suatu kontinum. Jarak antara kategori-kategori respon dinyatakan oleh jarak nilai z, yaitu merupakan titik letak bagi setiap kategori respons di sepanjang suatu kontinum yang berskala interval (Azwar, 2009). 
Tabel 1 menyajikan data deskriptif Kemandirian belajar siswa dalam matematika. Pada dasarnya, kemandirian belajar siswa dalam matematika meningkat setelah pelaksanaan pembelajaran, baik pada sekolah level tinggi, level sedang, level rendah maupun secara keseluruhan. Namun, peningkatan KBS ini masih rendah. Siswa pada sekolah level rendah yang mendapat pembelajaran dengan pendekatan PMR memperoleh peningkatan KBS relatif lebih tinggi dibandingkan dengan siswa lainnya. Untuk mengetahui apakah peningkatan (N-gain) KBS ini, serta perbedaan peningkatan KBS antar kelompok sampel berdasarkan level sekolah dan gabungan seluruh sampel adalah signifikan atau tidak, selanjutnya dilakukan uji statistik.

Sebelum melakukan uji statistik terhadap peningkatan KBS dan perbedaan peningkatan KBS kedua kelompok pembelajaran berdasarkan gabungan seluruh sampel dan level sekolah, terlebih dahulu dilakukan uji normalitas terhadap data yang digunakan, yaitu data awal, data akhir, dan data N-gain KBS dari kedua kelompok pembelajaran berdasarkan gabungan seluruh sampel dan level sekolah.
Untuk menguji signifikansi peningkatan KBS kelompok data yang berdistribusi normal, menggunakan Uji-t Berpasangan dan untuk kelompok data distribusinya tidak normal, menggunakan Uji Peringkat Bertanda Wilcoxon. Sementara, untuk menguji signifikansi perbedaan peningkatan KBS kelompok data yang berdistribusi normal, menggunakan uji Mann Whitney dan untuk kelompok data distribusinya tidak normal, menggunakan Uji-t Sampel Independen. Hipotesis statistik yang diuji menggunakan Uji-t Berpasangan adalah sebagai berikut:

$\mathrm{H}_{0}: \quad \mu_{1}=\mu_{2}$ (rata-rata data akhir KBS sama dengan rata-rata data awal KBS).

$\mathrm{H}_{1}: \quad \mu_{1}>\mu_{2}$ (rata-rata data akhir KBS lebih tinggi dari rata-rata data awal KBS)

Hipotesis statistik yang diuji menggunakan Uji Peringkat Bertanda Wilcoxon adalah sebagai berikut:

$\mathrm{H}_{0}: \eta_{1}=\eta_{2}$ (median data akhir KBS sama dengan median data awal KBS)

$\mathrm{H}_{1}: \quad \eta_{1}>\eta_{2}$ (median data akhir KBS lebih tinggi dari median data awal KBS) 
Tabel 1

Deskripsi Data Kemandirian Belajar Siswa dalam Matematika

\begin{tabular}{|c|c|c|c|c|c|c|c|}
\hline \multirow{3}{*}{ Kategori } & \multirow{3}{*}{$\begin{array}{l}\text { Statistik } \\
\text { deskriptif }\end{array}$} & \multicolumn{6}{|c|}{ Pendekatan Pembelajaran } \\
\hline & & \multicolumn{3}{|c|}{ PMR } & \multicolumn{3}{|c|}{ PB } \\
\hline & & $\begin{array}{c}\text { Data Awal } \\
\text { KBS }\end{array}$ & $\begin{array}{c}\text { Data Akhir } \\
\text { KBS }\end{array}$ & $\mathrm{N}$-gain & $\begin{array}{c}\text { Data Awal } \\
\text { KBS }\end{array}$ & $\begin{array}{c}\text { Data Akhir } \\
\text { KBS }\end{array}$ & $\mathrm{N}$-gain \\
\hline \multirow{3}{*}{$\begin{array}{c}\text { Sekolah } \\
\text { Level } \\
\text { Tinggi }\end{array}$} & $\mathrm{N}$ & 42 & 42 & 42 & 40 & 40 & 40 \\
\hline & Rata-Rata & 215.905 & 217.548 & 0.011 & 212.275 & 213.950 & 0.006 \\
\hline & Simpangan Baku & 18.314 & 17.397 & 0.122 & 21.454 & 22.273 & 0.189 \\
\hline \multirow{3}{*}{$\begin{array}{l}\text { Sekolah } \\
\text { Level } \\
\text { Sedang }\end{array}$} & $\mathrm{N}$ & 38 & 38 & 38 & 39 & 39 & 39 \\
\hline & Rata-Rata & 215.079 & 217.737 & 0.011 & 211.949 & 213.615 & 0.004 \\
\hline & Simpangan Baku & 22.610 & 23.767 & 0.265 & 21.704 & 22.027 & 0.205 \\
\hline \multirow{3}{*}{$\begin{array}{c}\text { Sekolah } \\
\text { Level } \\
\text { Rendah }\end{array}$} & $\mathrm{N}$ & 39 & 39 & 39 & 41 & 41 & 41 \\
\hline & Rata-Rata & 206.026 & 209.692 & 0.039 & 205.293 & 208.415 & 0.004 \\
\hline & Simpangan Baku & 21.840 & 23.833 & 0.167 & 20.865 & 15.893 & 0.211 \\
\hline \multirow{3}{*}{ Gabungan } & $\mathrm{N}$ & 119 & 119 & 119 & 120 & 120 & 120 \\
\hline & Rata-Rata & 212.403 & 215.034 & 0.020 & 209.783 & 211.950 & 0.004 \\
\hline & Simpangan Baku & 21.226 & 21.891 & 0.191 & 21.405 & 20.223 & 0.200 \\
\hline
\end{tabular}

Kriteria pengujian untuk menolak atau menerima $\mathrm{H}_{0}$ adalah: jika p-value (Sig. untuk Uji-t Berpasangan atau Asymp. Sig. untuk Uji Peringkat Bertanda Wilcoxon) kecil dari $\alpha=0,05$, maka $\mathrm{H}_{0}$ ditolak, dalam hal lainnya $\mathrm{H}_{0}$ diterima.

Tabel 2 menyajikan rangkuman hasil uji statistik terhadap peningkatan KBS kedua kelompok pembelajaran berdasarkan pendekatan pembelajaran dan level sekolah. Pada tabel tersebut, dapat dilihat bahwa p-value yang kecil dari 0,05 hanya dua, yaitu Sig.(1-sisi) kelompok pembelajaran dengan pendekatan PMR dan Asymp. Sig.(1-sisi) untuk sekolah level rendah dengan pendekatan PMR, yang menyebabkan penolakan $\mathrm{H}_{0}$.

Dengan demikian, dapat disimpulkan bahwa terjadi peningkatan kemandirian belajar siswa dalam matematika yang signifikan pada siswa yang belajar dengan pendekatan PMR secara keseluruhan dan pada sekolah level rendah. Sementara untuk kelompok lainnya tidak terjadi peningkatan yang signifikan. 


\section{Tabel 2}

Hasil Uji Statistik terhadap Peningkatan KBS

Berdasarkan Pendekatan Pembelajaran dan Level Sekolah

\begin{tabular}{|c|c|c|c|c|c|c|c|c|c|}
\hline \multirow{3}{*}{$\begin{array}{c}\text { No. } \\
\text { Hipo- } \\
\text { tesis }\end{array}$} & \multirow{3}{*}{ Faktor } & \multirow{3}{*}{$\begin{array}{c}\text { Kelompok } \\
\text { Pem- } \\
\text { belajaran }\end{array}$} & \multirow{3}{*}{$\mathrm{N}$} & \multicolumn{5}{|c|}{ Uji Statistik } & \multirow{3}{*}{ Keputusan } \\
\hline & & & & \multicolumn{2}{|c|}{$\begin{array}{c}\text { Uji Peringkat } \\
\text { Bertanda Wilcoxon }\end{array}$} & \multicolumn{3}{|c|}{ Uji-t Berpasangan } & \\
\hline & & & & Z & $\begin{array}{c}\text { Asymp. Sig. } \\
\text { (1-sisi) }\end{array}$ & $\mathrm{t}$ & $\mathrm{db}$ & $\begin{array}{c}\text { Sig. } \\
\text { (1-sisi) }\end{array}$ & \\
\hline \multirow{2}{*}{$\mathrm{a}$} & \multirow{2}{*}{$\begin{array}{l}\text { Pendekatan } \\
\text { Pembelajaran }\end{array}$} & PMR & 119 & & & 2.237 & 118 & .014 & $\mathrm{H}_{0}$ ditolak \\
\hline & & PB & 120 & & & 1.506 & 119 & .068 & $\mathrm{H}_{0}$ diterima \\
\hline \multirow{2}{*}{ c } & \multirow{2}{*}{$\begin{array}{c}\text { Sekolah } \\
\text { Level Tinggi }\end{array}$} & PMR & 42 & & & 1.291 & 41 & .102 & $\mathrm{H}_{0}$ diterima \\
\hline & & PB & 40 & & & .739 & 39 & .232 & $\mathrm{H}_{0}$ diterima \\
\hline \multirow{2}{*}{ e } & \multirow{2}{*}{$\begin{array}{c}\text { Sekolah } \\
\text { Level Sedang }\end{array}$} & PMR & 38 & & & 1.142 & 37 & .131 & $\mathrm{H}_{0}$ diterima \\
\hline & & PB & 39 & & & .596 & 38 & .278 & $\mathrm{H}_{0}$ diterima \\
\hline \multirow[b]{2}{*}{$\mathrm{g}$} & \multirow{2}{*}{$\begin{array}{c}\text { Sekolah } \\
\text { Level Rendah }\end{array}$} & PMR & 39 & -1.671 & .048 & & & & $\mathrm{H}_{0}$ ditolak \\
\hline & & PB & 41 & & & 1.272 & 40 & .106 & $\mathrm{H}_{0}$ diterima \\
\hline
\end{tabular}

Selanjutnya, dilakukan pengujian

$\mathrm{H}_{1}: \quad \eta_{1}>\eta_{2}$ (median N-gain KBS

inferensial untuk melihat apakah

perbedaan peningkatan tersebut signifikan atau tidak, yaitu pengujian terhadap hipotesis $b$ dan $h$. Sementara untuk hipotesis d dan $\mathrm{f}$ tidak perlu lagi pengujian statistik karena peningkatan kemandirian belajar masing-masing kelompok tersebut tidak signfikan. Statistik uji yang digunakan adalah uji non parametrik Mann Whitney karena kedua kelompok data yang diujikan tidak berdistribusi normal.

Hipotesis statistik yang diuji menggunakan Uji Mann Whitney adalah:

$\mathrm{H}_{0}: \quad \eta_{1}=\eta_{2}$ (median N-gain KBS siswa yang mendapat pembelajaran dengan pendekatan PMR sama dengan median N-gain KBS siswa yang siswa yang mendapat pembelajaran dengan pendekatan PMR lebih tinggi dari median $\mathrm{N}$-gain KBS siswa yang mendapat pembelajaran dengan pendekatan $\mathrm{PB})$.

Kriteria pengujian yang digunakan untuk uji statistik tersebut adalah: jika pvalue (Sig. untuk Uji-t Sampel Independen atau Asymp. Sig. untuk Uji Mann Whitney) lebih kecil dari $\alpha=0,05$, maka $\mathrm{H}_{0}$ ditolak, dalam hal lainnya $\mathrm{H}_{0}$ diterima. Pada Tabel 3 dapat dilihat bahwa untuk setiap faktor, Asymp. Sig. (1-sisi) yang diberikan oleh Uji Mann Whitney lebih besar dari 0,05. Oleh karena itu, untuk setiap faktor, $\mathrm{H}_{0}$ diterima. Rangkuman hasil pengujiannya disajikan pada Tabel 3.

mendapat pembelajaran dengan pendekatan PB) 
Tabel 3

Hasil Uji Statistik terhadap Perbedaan Peningkatan KBS

\begin{tabular}{|c|c|c|c|c|c|}
\hline \multirow{2}{*}{ No. Hipotesis } & \multirow{2}{*}{ Faktor } & \multirow{2}{*}{$\mathrm{N}$} & \multicolumn{2}{|c|}{ Uji Mann Whitney } & \multirow{2}{*}{ Keputusan } \\
\hline & & & $\mathrm{Z}$ & Asymp. Sig.(1-sisi) & \\
\hline $\mathrm{b}$ & $\begin{array}{c}\text { Pendekatan } \\
\text { Pembelajaran }\end{array}$ & 239 & -.624 & .266 & $\mathrm{H}_{0}$ diterima \\
\hline $\mathrm{h}$ & $\begin{array}{c}\text { Sekolah } \\
\text { Level Rendah }\end{array}$ & 80 & -.279 & .390 & $\mathrm{H}_{0}$ diterima \\
\hline
\end{tabular}

Dengan demikian peningkatan

kemandirian belajar siswa dalam matematika bagi siswa yang belajar matematika dengan pendekatan PMR tidak lebih tinggi secara signifikan dibanding dengan kemandirian belajar siswa dalam matematika bagi siswa yang belajar matematika dengan pendekatan $\mathrm{PB}$, baik berdasarkan pendekatan pembelajaran maupun pada sekolah level rendah.

Kemudian, pengujian dilanjutkan berdasarkan aspek KBS untuk mengetahui pada aspek apa saja, peningkatan KBSPMR lebih tinggi secara signifikan dibadingkan dengan peningkatan KBS-PB, selanjutnya dilakukan pengujian untuk

Tabel 4

Hasil Uji Mann Whitney terhadap Perbedaan Peningkatan pada Setiap Aspek KBS Berdasarkan Pendekatan Pembelajaran

\begin{tabular}{|l|r|r|r|r|}
\hline & $\begin{array}{c}\text { N-gain KBS } \\
\text { Aspek_KM }\end{array}$ & $\begin{array}{c}\text { N-gain KBS } \\
\text { Aspek_MSD }\end{array}$ & $\begin{array}{c}\text { N-gain KBS } \\
\text { Aspek_SM }\end{array}$ & $\begin{array}{c}\text { N-gain KBS } \\
\text { Aspek_SK }\end{array}$ \\
\hline Mann-Whitney U & 6978.000 & 6938.000 & 6908.500 & 6021.000 \\
\hline Z & -.303 & -.378 & -.434 & -2.095 \\
\hline Asymp. Sig. (1-sisi) & .381 & .353 & .333 & .018 \\
\hline
\end{tabular}

Dari Tabel 4 diketahui bahwa Uji Mann Whitney memberikan nilai Asymp. Sig. (1-sisi) kepada N-gain KBS pada masing-masing aspek KBS. Sebelumnya dilakukan terlebih dahulu uji normalitas data N-gain masing-masing aspek KBS, yang hasilnya digunakan sebagai dasar pemilihan uji statistik. Dari hasil pengujian normaliti, diperoleh hasil bahwa setiap aspek KBS pada kedua kelompok pembelajaran tidak berdistribusi normal. Oleh sebab itu, untuk menguji signifikansi perbedaan peningkatan KBS berdasarkan aspek-aspeknya, antara siswa yang belajar dengan pendekatan PMR dan siswa yang belajar dengan pendekatan PB, menggunakan uji Mann Whitney. Hasil pengujiannya dapat dilihat pada Tabel 4. 
sisi lain, uji Mann Whitney memberikan nilai Asymp. Sig. (1-sisi) > 0,05 kepada aspek KBS lainnya, yang merupakan bukti kuat untuk menerima $\mathrm{H}_{0}$. Dengan demikian, peningkatan KBS pada aspek startegi kognitif bagi siswa yang belajar melalui pendekatan PMR lebih tinggi secara signifikan dibandingkan dengan siswa yang belajar melalui pendekatan PB, sementara pada aspek KBS lainnya tidak terdapat perbedaan yang signifikan.

\section{Pembahasan}

Dari pelaksanaan pembelajaran dengan pendekatan PMR, diperoleh hasil peningkatan kemandirian belajar siswa dalam matematika (KBS) seperti yang disajikan pada Tabel 1. Pada dasarnya, terdapat peningkatan KBS bagi siswa yang belajar matematika melalui pendekatan PMR, baik ditinjau dari keseluruhan maupun berdasarkan level sekolah. Namun berdasarkan hasil pengujian secara statistik, peningkatan secara signifikan hanya terjadi pada siswa di sekolah level rendah dan pada siswa yang belajar matematika melalui pendekatan PMR secara keseluruhan.

Di sisi lain, bagi siswa yang belajar matematika melalui pendekatan PB tidak mengalami peningkatan KBS secara signifikan, baik secara keseluruhan maupun berdasarkan berdasarkan level sekolah. Hal ini menunjukkan adanya pengaruh pendekatan PMR terhadap peningkatan KBS, walaupun pengaruhnya masih tergolong kecil.

Dari hasil pengujian secara statistik yang disajikan pada Tabel 2 dan Tabel 3, diketahui bahwa perbedaan peningkatan KBS antara siswa yang belajar matematika melalui pendekatan PMR dan PB tidak signifikan, baik ditinjau secara keseluruhan maupun berdasarkan level sekolah. Akan tetapi, peningkatan KBS pada aspek strategi kognitif, bagi siswa yang belajar matematika melalui pendekatan PMR lebih tinggi secara signifikan dibandingkan dengan siswa yang belajar matematika melalui pendekatan PB ditinjau dari keseluruhan.

Kecilnya pengaruh pendekatan PMR terhadap peningkatan KBS pada penelitian ini, agaknya disebabkan oleh pelaksanaan penelitian dalam waktu yang relatif singkat. Menurut Zimmerman, Bonner, dan Kovach (1996), untuk melatih satu indikator keterampilan kemandirian belajar, misalnya: manajemen dan perencanaan waktu, diperkirakan membutuhkan waktu lima minggu. Oleh sebab itu, sangatlah wajar jika pada penelitian ini peningkatan kemandirian belajar siswa dalam matematika sangat rendah, sehingga belum memberikan 
perbedaan yang signifikan dengan siswa di kelas kontrol, karena siswa hanya mendapat latihan sekitar tiga bulan untuk mengembangkan 10 indikator kemandirian belajar, padahal seharusnya siswa mendapatkan latihan selama lebih kurang 50 minggu (hampir satu tahun).

Hal senada juga disampaikan oleh Schunk dan Zimmerman (dalam Sumarmo, 2006), bahwa latihan menerapkan kemandirian belajar secara ekstensif diberikan dalam waktu yang lama dan diikuti dengan pemberian umpan balik yang informatif dan korektif. Bahkan menurut Winne dan Nesbit (2009), untuk mengembangkan keahlian dalam suatu mata pelajaran, seperti dalam kemandirian belajar yang komplek, siswa memerlukan waktu kira-kira 10,000 jam praktek yang disengaja. Namun demikian, mereka menambahkan bahwa sesungguhnya para siswa hampir tidak menggunakan waktu yang cukup untuk mengerjakan PR dan aktivitas di kelas untuk mencapai batas ini.

Faktor lain yang menyebabkan kecilnya data peningkatan KBS ini, diduga berkaitan dengan keakuratan data yang dikumpulkan, di mana data KBS yang dikumpulkan belum mencerminkan fakta yang sesungguhnya. Ada beberapa faktor yang disinyalir mempengaruhi keakuratan data. Pertama, berhubungan dengan metode pengumpulan data. Pada penelitian ini, pengumpulan data KBS hanya dilakukan melalui angket pelaporan-diri, yang terdiri dari pernyataan-pernyataan dengan lima pilihan. Walaupun angket pelaporan-diri merupakan instrumen yang banyak digunakan untuk mengukur kemandirian belajar (lihat Montalvo dan Tores, 2004), dan pada penelitian ini angket skala KBS yang digunakan mempunyai reliabilitas yang tinggi $(0,93)$, serta item-itemnya memenuhi persyaratan kevalidan, namun angket ini mempunyai kelemahan, di mana siswa tidak mendapat kesempatan untuk menjawab sesuai dengan apa yang sesungguhnya mereka rasakan atau alami. Mereka harus memilih salah satu dari pilihan yang ada. Pada hal (Zimmerman, 1990), dengan mengonstruk jawaban sendiri lebih mendekati kondisi yang sesungguhnya tentang kemandirian belajar siswa daripada dalam bentuk pilihan ganda.

Zimmerman dan Martinez-Pons (dalam Zimmerman, 1990) menambahkan, bahwa usaha selanjutnya untuk mendapatkan data yang akurat tentang kemandirian belajar siswa adalah memvalidasi kebenaran dari jawaban siswa tentang strategi kemandirian belajar yang mereka gunakan dengan menanyakan kepada guru mereka untuk menilai strategi 
yang digunakan oleh siswa dengan menggunakan skala model likert.

Kedua, berkaitan dengan kemampuan siswa dalam menilai diri. Pada awalnya, beberapa siswa mempunyai self-confidence yang relatif tinggi terhadap kemampuan kemandirian belajar mereka sehingga ketika mengisi angket skala KBS sebelum pembelajaran, mereka cenderung memberikan penilaian yang tinggi. Seperti yang dikemukakan oleh Mohan dan Lundeberg (2009), bahwa siswa cenderung terlalu yakin tentang pemahaman mereka, terutama sebelum mereka menguji pemahaman mereka. Namun, ketika pembelajaran berjalan, siswa baru menyadari tentang kemampuannya, dan kemudian mereka belajar menilai diri, sehingga kemampuan mereka menilai diri semakin baik. Hal ini mengakibatkan penilaian siswa terhadap KBS mereka pada akhir pembelajaran tidak jauh berbeda dengan pada awal pembelajaran. Jadi, rendahnya gain KBS tersebut diduga bukan karena kecilnya peningkatan sesungguhnya, tetapi karena adanya perbedaan kemampuan siswa dalam menilai kompetensi diri.

Jadi, dapat dipahami mengapa data KBS pada penelitian ini memperlihatkan peningkatan yang relatif kecil.

\section{KESIMPULAN DAN SARAN}

Hasil penelitian ini menunjukkan bahwa siswa yang belajar matematika dengan pendekatan PMR mendapat peningkatan kemandirian belajar yang signifikan, ditinjau dari keseluruhan sampel dan pada sekolah level rendah, sedangkan siswa yang belajar matematika dengan pendekatan PB tidak mengalami peningkatan kemandirian belajar yang signifikan, baik ditinjau dari keseluruhan sampel maupun berdasarkan level sekolah. Selanjutnya, peningkatan kemandirian belajar siswa dalam matematika pada aspek strategi kognitif bagi siswa yang belajar matematika dengan pendekatan PMR lebih tinggi secara signifikan dibandingkan dengan siswa yang belajar matematika melalui pendekatan PB. Hasil penelitian ini membuktikan bahwa pendekatan PMR relatif lebih unggul dibandingkan dengan pendekatan $\mathrm{PB}$ dalam hal meningkatkan kemandirian belajar siswa dalam matematika.

Oleh karena itu, peneliti memberikan saran bahwa guru dapat menggunakan pendekatan PMR sebagai alternatif pendekatan pembelajaran matematika untuk meningkatkan kemandirian belajar siswa dalam matematika terutama pada aspek strategi kognitif, namun pendekatan ini hendaknya 
diterapkan dalam waktu yang lebih lama agar siswa mendapat pelatihan yang memadai sehingga mendapatkan peningkatan kemandirian belajar yang lebih tinggi.

\section{DAFTAR PUSTAKA}

Abdullah, M.N.L.Y. (2007). "Exploring Children's Self-Regulated Learning Skills". Makalah pada Konferensi Internasional Tentang Reformasi Pendidikan Ke-1, Bangkok.

Ary, D., Jacobs, L. C., dan Sorensen, C. (2010). Introduction to Research in Education (edisi kedelapan). Canada: Wadsworth, Cengage Learning.

Azwar, S. (2009). Dasar-Dasar Psikometri. Yogyakarta: Pustaka Pelajar.

Bandura, A. (1997). Self-Efficacy; The Exercise of Control. New York: W.H. Freeman and Company.

Camahalan, F.M.G. (2006). Effects of Selfregulated Learning on Mathematics Achievement of Selected Southeast Asian Children. [Online]. Tersedia: http://findarticles.com/p/articles [12 Maret 2010].

Cobb, R. (2003). The Relationship between Self-Regulated Learning Behaviors and Academic Performance in Web-Based Courses. Disertasi pada State University: Tidak diterbitkan.

Darr, C. Dan Fisher, J. (2004). SelfRegulated Learning In The
Mathematics Class. [online]. Tersedia: http://www.nzcer.org.nz/pdfs/1390 3.pdf [15 Maret 2010].

De Corte, E., Verschaffel, L., dan Op'T Eynde, P. (2000), "Self-Regulation a Characteristic and a Goal of Mathematics Education". Dalam D.J. Hacker, J. Dunlosky, dan A.C. Graesser (Eds.). Handbook of Metacognition in Education. 259 277. New York: Routledge.

Gravemeijer, K.P.E. (1994). Developing Realistic Mathematics Education. Utrecht: Freudenthal Institute.

Mohan, L. dan Lundeberg, M. (2009). "Context Matters Gender and Cross-Cultural Differences in Confidence". Dalam D.J.Hacker, J. Dunlosky, dan A.C. Graesser (Eds.). Handbook of Metacognition in Education, 221 - 239. New York: Routledge.

Montalvo, F.T. dan Torres, M.C.G. (2004). "Self-Regulated Learning: Current and Future Directions". Electronic Journal of Research Psychology. 2, (1), 1-34.

Muijs, D. (2004). Doing Quantitative Research in Education with SPSS. Great Britain: Athenaeum Press Ltd.

Pintrich, P. R. dan Groot, E. V. D. (1990). "Motivational and Self-Regulated Learning Components of Classroom Academic Performance". Journal of Education Psychology. 82, (1), 3334.

Sumarmo, U. (2006). Kemandirian Belajar: Apa, Mengapa, dan 
Bagaimana Dikembangkan pada Peserta Didik. [Online]. Tersedia: http://math.sps.upi.edu/wp-content [6 Maret 2010].

Winne, P.H. dan Nesbit, J.C. (2009). "Supporting Self-Regulated Learning with Cognitive Tools". Dalam D.J. Hacker, J. Dunlosky, dan A.C. Graesser (Eds.). Handbook of Metacognition in Education, 259 - 277. New York: Routledge.

Winne, P.H. dan Perry, A.N.E. (2005). "Measuring Self-Regulated Learning". Dalam M. Boekaerts, P.R. Pintrich, dan M. Zeidner (Eds.). Handbook of SelfRegulation, 531 - 566. San Diego: Academic Press.

Wolters, C.A., Pintrich, P.R., dan Karabenick, S.A. (2003). "Assessing Self-Regulated Learning". Makalah pada the Conference on Indicators of Positive Development: Definitions, Measures, and Prospective Validity, National Institutes of Healty.
Zimmerman, B.J, Bonner, S., dan Kovach, R. (1996). Developing SelfRegulated Learners Beyond Achievement to Self-Efficacy. Washington, DC: American Psychological Association.

Zimmerman, B.J. (1990). Sel-Regulated Learning and Academic Achievement: An Overview. Journal of Education Psychology. 25, (1), 3-17. 